\title{
(NE)OSTVARENO Strateški istraživački i nakladnički projekti hrvatske povijesti umjetnosti: sinteza - umjetnička topografija - korpusi - monografije
}

Pelc, Milan; Domljan, Žarko; Jurković, Miljenko; Maroević, Tonko; Reberski, Ivanka

Source / Izvornik: Institucije povijesti umjetnosti : zbornik 4. kongresa hrvatskih povjesničara umjetnosti, 2019, 295 - 302

Conference paper / Rad u zborniku

Publication status / Verzija rada: Published version / Objavljena verzija rada (izdavačev PDF)

https://doi.org/10.31664/24khpu.38

Permanent link / Trajna poveznica: https://urn.nsk.hr/urn:nbn:hr:254:259875

Rights / Prava: Attribution 4.0 International/Imenovanje 4.0 međunarodna

Download date / Datum preuzimanja: 2023-04-26

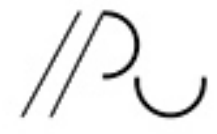

INSIITUTZZA POVIJESTUMJETNOST
Repository / Repozitorij:

PODEST - Institute of Art History Repository

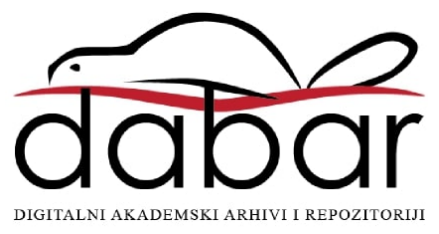




\section{(NE)OSTVARENO \\ Strateški istraživački \\ i nakladnički projekti \\ hrvatske povijesti umjetnosti: \\ sinteza-umjetnička topografija- \\ -korpusi-monografije}

Milan Pelc

Žarko Domljan

Miljenko Jurković

Tonko Maroević

Ivanka Reberski

Milan Pelc

voditelj panela

Žarko Domljan, Miljenko Jurković, Tonko Maroević, Ivanka Reberski sudionici panela

Kao što naznačuje njegov podnaslov, panel je priređen s ciljem da se retrospektivno i analitički razmotri provedba dugoročnih strateških projekata i programa povijesnoumjetničke struke u Hrvatskoj nakon Drugoga svjetskog rata. Rad na tim projektima podrazumijeva razvijanje ključnih modela istraživanja, obrade i prezentacije nacionalne umjetničke baštine i umjetničkih pojava na domaćem i međunarodnom planu. To su projekti koji se uglavnom ne mogu ostvariti bez institucijske potpore te je u njihovoj provedbi jednako važna suradnja institucija i istraživača kao i suradnja institucija međusobno.

$\mathrm{Na}$ provedbi navedenih projekata desetljećima je bio angažiran Institut za povijest umjetnosti u Zagrebu. Projekti su ostvareni tek djelomično, odnosno rad na njima još traje. Razgovorom na panelu željelo se ustanoviti odvija li se ostvarivanje tih projekata zadovoljavajućim tempom te dokle je došla i zbog čega eventualno zapela njihova realizacija. Svaki je od tih projekata specifičan i nosi vlastite zamke koje otežavaju njegovo ostvarivanje. O svemu tome svoja su zapažanja iznijeli sudionici okruglog stola, eminentni znanstvenici, istaknuti predstavnici struke i sudionici kulturnog života Hrvatske druge polovine 2o. stoljeća Žarko Domljan, Miljenko Jurković, Tonko Maroević i Ivanka Reberski.

Žarko Domljan, povjesničar umjetnosti i leksikograf koji je sudjelovao u izradi i vodio niz važnih leksikografskih projekata koji se tiču povijesti umjetnosti u Hrvatskoj, a to su u prvom redu Likouna enciklopedija Jugoslavije i Enciklopedija Hrvatske Umjetnosti, bio je u Institutu za povijest umjetnosti jedan od urednika prvih izdanja umjetničke topografije i programa sinteznog pregleda hrvatske povijesti umjetnosti. Kao sudionik u izgradnji struke od šezdesetih godina 2o. stoljeća Žarko Domljan dao je nekoliko kritičkih opaski o općem stanju u hrvatskoj povijesti umjetnosti kako ga on razumijeva i vidi. Ovdje te opaske donosimo u sažetom obliku: I. Postoji atmosfera nezamjeranja među kolegama, nedostaje kritičkih osvrta i stručne polemike. Sve same pohvale i panegirici. Takva je atmosfera nezdrava za struku. 2. Prečesto se u radovima zanemaruje vrijednosni kriterij, čime dolazi do nekritičkog gomilanja materijala. Tako nastaju knjige koje se jedva drže u ruci i izložbe na kojima trećina djela nema umjetničke vrijednosti. Sve što ne može 
izdržati vrijednosni kriterij pripada doduše povijesti, ali ne i povijesti umjetnosti! 3. Većina kolega preferira specijalističke teme, teško se odlučuju za šire zahvate, što zahtijeva više vremena i truda. To je jedan od razloga zašto se teško ostvaruju odnosno ostaju neostvareni ambiciozniji stručni projekti. 4. Morao bi postojati dugoročni plan istraživanja i prezentacije naše nacionalne umjetničke baštine, i to u obliku zajedničke redakcije, koja bi pratila i godišnje evaluirala izvršenje plana. Nužno je objavljivanje radova na stranim jezicima, bez čega ostajemo u svijetu nepoznati. 5. Jedan od glavnih nedostataka, ne samo u našoj struci, jest nepostojanje jasnoga vodstva, a to znači čvrste organizacije i zatim koordinacije među glavnim akterima projekata. To se očitovalo kod sinteznog pregleda, a još više kod umjetničke topografije.

U svom doprinosu panelu Žarko Domljan se izlaganjem u prvom redu osvrnuo na historijat izrade sinteznog pregleda povijesti umjetnosti u Hrvatskoj, u kojem je aktivno sudjelovao dugi niz godina.

\section{Žarko Domljan - Nastanak i tijek projekta sinteznog pregleda umjetnosti u Hrvatskoj}

Radeći u Leksikografskom zavodu u redakciji Enciklopedije likovnih umjetnosti Žarko Domljan stekao je široki uvid u struku i shvatio koliko nam nedostaje cjeloviti pregled umjetnosti u Hrvatskoj, nešto poput Babićeve knjige Umjetnost u Hrvata (I934.), koji bi na sumaran način dao pregled cjelokupne hrvatske umjetnosti od najranijih početaka, tj. od prapovijesti do današnjeg dana, ali iz pera kompetentnih stručnjaka i sa suvremenog stanovišta. Tu je ideju razradio I969. u obliku Sinteznog pregleda umjetnosti u Hrvatskoj u sedam knjiga i predložio je upravnom odboru Matice hrvatske. Svrha izdanja bila bi da stručnjacima pokaže gdje su nam istraživanja bila nedostatna i kamo treba usmjeriti snage, a široj publici da pokaže domete i vrijednosti koje je hrvatski narod tijekom povijesti postigao u umjetničkom stvaralaštvu. Pregled bi imao dvostruku funkciju, užu stručnu i širu nacionalno-popularizacijsku. Matica hrvatska prihvatila je ponuđeni projekt, koji je Žarko Domljan u međuvremenu detaljno razradio i u sedam knjiga trebalo se obuhvatiti ova razdoblja: prapovijest i antika, predromanika i romanika, gotika, renesansa, barok, devetnaesto i dvadeseto stoljeće. Početkom 1970. sklopljeni su prvi ugovori s autorima.

U međuvremenu slomljeno je Hrvatsko proljeće, a Matica hrvatska zabranjena. Započeti projekt sinteznog pregleda kao i časopis Život umjetnosti, čiji je glavni urednik bio Žarko Domljan, ostali su bez izdavača i bez financija, pa ih je prvo preuzelo Društvo povjesničara umjetnosti (predsjednik je tada bio Žarko Domljan) te poslije Institut za povijest umjetnosti. Prema riječima Žarka Domljana, projekt sinteznog pregleda dočekan je u Institutu za povijest umjetnosti s rezervom jer su pojedinci tvrdili da se treba baviti samo fundamentalnim istraživanjima, kojima se ne može unaprijed odrediti opseg i rok, a ovdje se radi o nekoj površnoj, kompilatorskoj sintezi, koja nema veze s istraživanjem i novim znanstvenim otkrićima. Takvo je stanje potrajalo nekoliko godina.

Prva knjiga objavljena je ig82. godine u malom formatu i s crno-bijelim reprodukcijama. Na knjizi je navedeno čak pet izdavača: Sveučilišna naklada Liber, Institut za povijest umjetnosti (tada Odjel za povijest 
umjetnosti Centra za povijesne znanosti Sveučilišta u Zagrebu), Društvo povjesničara umjetnosti Hrvatske, Grafički zavod Hrvatske i Kršćanska sadašnjost. Izdavanje sinteznog pregleda preuzela je potom Naklada Naprijed (danas Ljevak) koja je već objavila nekoliko knjiga u seriji Povijest umjetnosti u Hrvatskoj, u prikladnom formatu i reprodukcijama u boji. Dogovoreno je da kuća Naprijed bude izdavač budućih izdanja, a Institut za povijest umjetnosti pružat će i dalje stručne usluge.

Do sada je objavljeno: Barok u Hrvatskoj (Anđela Horvat, Radmila Matejčić, Kruno Prijatelj, I982.), Prapovijest (Stojan Dimitrijević, Tihomila Težak-Gregl, Nives Majnarić-Pandžić, r998.), Antika (Nenad Cambi, 2002.), Renesansa (Milan Pelc, 2007.), Hrvatsko slikarstvo od 1945. do danas (Sandra Križić Roban, 2013.), Hruatsko kiparstvo od r95o. do danas (Ive Šimat Banov, 20I3.), Barokna arhitektura (Katarina Horvat-Levaj, 20I5.).

Tomu treba dodati i pet knjiga Grge Gamulina, koje nisu nastale u okviru projekta, ali su objavljene kod istoga izdavača, u istom formatu i opremi i u okviru iste serije Povijest umjetnosti u Hrvatskoj: Hrvatsko slikarstvo XIX. stoljeća, sv. I. (I995.), Hrvatsko slikarstvo na prijelazu iz XIX. u XX. stoljeće, sv. II (I995.), Hrvatsko slikarstvo XX. stoljeća, sv. I., drugo izdanje (I997.), Hrvatsko slikarstvo XX. stoljeća, sv. II., drugo izdanje (I997.), Hruatsko kiparstuo XIX. i XX. stoljeća (I999.).

Iz svega što je rečeno vidljivo je da je projekt sinteznog pregleda umjetnosti u Hrvatskoj, koji je začet davne ig69. godine u krilu Matice hrvatske, imao težak, krivudav i trnovit put, a danas se nastavlja kao nosivi izdavački projekt Naklade Ljevak uz stručnu potporu Instituta za povijest umjetnosti. Ideja da nam je nužan cjelovit pregled nacionalnog umjetničkog stvaralaštva dobiva sve više pristalica u struci i ona je unutrašnja snaga koja taj projekt pokreće i desetljećima održava na životu.

Miljenko Jurković, redoviti profesor na Odsjeku za povijest umjetnosti Filozofskog fakulteta Sveučilišta u Zagrebu, također je bio pozvan da sudjeluje na panelu. Poziv je prihvatio, no kako zbog neodgodiva puta nije mogao biti nazočan, u svom doprinosu ovom zborniku dodatno se osvrnuo na pitanje izrade umjetničkih korpusa.

\section{Miljenko Jurković - Korpusi umjetničke baštine Hrvatske: iskustva s kasnom antikom i ranim srednjim vijekom}

Izrada korpusa određenog segmenta povijesnoumjetničke baštine uvijek se pokazuje kao teška zadaća: iziskuje rad, vrlo često i fizički, a ne samo domišljanja u kabinetu; iziskuje i znanstvenu rigoroznost, jer ne trpi improvizacije, neprovjerljive ideje ili teze, iziskuje samo i isključivo poštivanje faktografije. Korpus je, dakle, samo oruđe za rad, usporediv s kompjutorskim programom, on je samo podloga, baza, za bilo koje dalje istraživanje.

No suvremena povijest umjetnosti-ne onakva kakva postoji već više od dva stoljeća-već jedna nova, uklopljena u šira antropološka istraživanja, ne može više bez korpusa spomeničke građe. Lijepa, romantična povijest umjetnosti jest prošlost. Danas je to znanost koja se sve više nastoji zasnivati na čvrstim, materijalnim dokazima, dopuštajući interpretacijama tek malo prostora. Stoga su korpusi nužnost sadašnjosti.

Korpus ranosrednjovjekovne skulpture radi se već gotovo pola stoljeća u Italiji. Objavljeno je tridesetak svezaka u tom vremenskom rasponu, no nije još pokriveno ni pola Italije. Korpus fragmenata 
ranosrednjovjekovne skulpture važan je za izradu komparativne analize motiva, odnosno rekonstrukciju cjelovitog komada. No, našim talijanskim kolegama nije nikad palo na pamet da prvo probaju rekonstruirati jednu, primjerice, oltarnu ogradu, pa je onda takvu objaviti sa svim svojim fragmentima, što ukazuje na slabosti jednog ipak postojećeg korpusa u dugom nastajanju.

U Francuskoj su I980-ih izdana četiri sveska, Nijemci su uspjeli pokriti Bavarsku, a ostali nisu ni pokušali.

Ima ipak i uspješnijih primjera. Nekoliko godina unatrag izrađen je korpus umjetničkih transfera u Europi u vrijeme gotike, koji je pokrio mobilnost umjetnika u navedenom razdoblju. Počevši s velikim ambicijama na kraju je taj korpus obuhvatio samo poznata imena kojima se moglo atribuirati neko djelo. Onaj golemi posao koji je u nas na temelju arhivskih istraživanja obavila tako davno Nevenka Bezić Božanić nije se unatoč velikim željama u Europi ostvario.

Ima i uspješnih primjera poput Corpus vitrearum medii aevi koji se već duže provodi u zapadnoeuropskim zemljama, i to je po mojim saznanjima najozbiljniji korpus povijesnoumjetničke struke, ako zanemarimo korpuse keramike i sličnih sitnih inventara.

U Hrvatskoj kao i drugim zemljama u Europi, preferiraju se sinteze od korpusa. To je posve razumljivo jer je jedno kreativan rad, drugo pak mukotrpno slaganje fragmenata. A još nam nije jasno da se bez korpusa više ne može.

Dobar nam je primjer srednjovjekovno fresko slikarstvo, kojeg poznajemo zahvaljujući u prvom redu Branku Fučiću za Istru ili izložbi romaničkoga slikarstva i katalogu Igora Fiskovića. To jesu katalozi, i to prilično obuhvatni, ali to nisu korpusi. Nisu rađeni striktnom metodologijom, nisu napravljene ekstenzivne kataloške jedinice, nisu obuhvaćeni svi analitički aspekti, a još manje kontekstualizacija.

Dosad je objavljeno možda tek dvadesetak posto sveukupne kasnoantičke i ranosrednjevjekovne skulpture, a sve ostalo čami u depoima muzeja. Tim temama posvećeno je više magisterija i doktorata, koji sadrže i kataloge, no oni nisu potpuni, pa u tom smislu nisu korpusi. Nijedan pokušaj da se iz tih kataloga dobije korpus nije uspio. Ne postoji razumijevanje da je korpus osnovni radni alat bez kojega zaključci o određenim problemima mogu biti znatno fluidniji nego u slučaju da on postoji.

Budući da ne postoji svijest o nužnosti, nema ni svijesti financijaša, a izrada korpusa je skupa. Korpusi se uglavnom ne prijavljuju kao projekti jer zahtijevaju mnogo posla, a rezultati nisu u znanstvenom smislu vidljivi odmah po dovršetku projekta. Posao se zapravo ne želi ni započeti. Nije to pitanje opremljenosti institucija, ni ikakvih društvenih okolnosti, ni neodgovornosti prema nacionalnoj baštini. To je više pitanje komocije.

Dakako, postoji i optimistična verzija cijele priče. Dokaz je korpus na kojem se intenzivno radi i koji je metodološki definiran i dobro napreduje. Riječ je o Corpus architecturae religiosae europeae (IV-X saec.).

Projekt je začet 200o. godine u okviru rada Međunarodnog istraživačkog centra za kasnu antiku i srednji vijek Sveučilišta u Zagrebu. Pokrenuli smo ga prof. Gian Pietro Brogiolo iz Padove i ja, objavivši namjeru, svojevrsni apel, u Bulletin de l'Association pour l'antiquite tardive, uz svesrdno sudjelovanje Noela Duvala.

Osam godina sastajali smo se dva puta godišnje na simpozijima motovunskog centra i u Padovi, šireći radnu grupu i radeći na metodologiji. Osam je godina trebalo da iznjedrimo katalošku jedinicu za sakralnu arhitekturu od 4. do ıo. stoljeća. Ta je kataloška jedinica potpuna, ona 
obuhvaća skulpturu, slikarstvo, liturgijske instalacije, epigrafiku, grobove, predmete umjetničkog obrta, izvore itd. Ta je kataloška jedinica službeno objavljena 20I2. (prevedena je na pet jezika kojima se korpus smije služiti-engleski, francuski, njemački, talijanski i španjolski) u Hortus Artium medievalium ı8/ı, u uvodnome tekstu koji temeljito objašnjava razloge pokretanja korpusa i njegove izrade. Proces nastajanja bio je dug, no metodologija je izbalansirana, a procesi i provedba temeljito utanačeni.

U međuvremenu je, 2009., objavljen i prvi svezak kao pilot-projekt, da bi se ustanovila važnost samoga korpusa i dobile prve povratne informacije. Taj će se svezak na kraju procesa ponovno tiskati, ažuriran i biti usklađen sa svim ostalima, kojih zasad predviđamo između pedeset i šezdeset. Iako je već desetak volumena gotovo spremno za tisak, ne želimo upasti u zamku pedesetogodišnjeg rada i golemih razlika između svezaka, pa čekamo kritičnu masu gotovih regija da bismo krenuli u tisak u ritmu svaka tri do četiri mjeseca jedan svezak.

Jednako je tako u prvom desetljeću kreiranja korpusa rađeno na informatizaciji i usklađivanju dokumentacije. Određeni su parametri izrade tlocrta i nacrta, ali ujednačeno i uniformno korištenje tipova i debljina linija te boja koje označavaju stoljeća. I ne samo da je u čitavoj Europi danas to posve ujednačeno za korpus, nego se svi kolege u publiciranju svojih rezultata drže tog istog protokola.

Paralelno s tim poslom radilo se na informatičkom programu za izradu korpusa dostupna na internetu. Francuska ekipa dovršila je program nazvan wiki bridge, koji sada koriste svi koji su krenuli u izradu korpusa. Tiskani i on-line korpus nisu identični te internetski sadržava više podataka koji se dopunjuju. U svakoj zemlji postoji administrator koji može ući u svaku katalošku jedinicu, pod njim su regionalni urednici koji mogu kontrolirati svoju regiju, a danas već gotovo tisuću osoba ispunjava on-line kataloške jedinice. Pokusno je objavljen samo dio francuskog korpusa.

Počelo se s nekoliko zemalja: Hrvatska, Italija, Francuska, Španjolska. Pridruživale su se postupno ostale, da bismo danas pokrivali gotovo čitavu Europu. Naravno, nisu sve zemlje $u$ istom ritmu niti jednako napredovale. Količina građe također nije jednaka. Primjerice, Poljska, Češka, Slovačka, Mađarska zajedno čine jedan svezak, Hrvatska ih ima četiri, a u Italiji samo Rim ima četiri sveska.

Kada se zna što je cilj, kada postane jasno da u globaliziranom prostoru više nitko ne može raditi zatvoren u svoj mali zavičaj, i kada postoji želja za spoznajama, onda je sve moguće učiniti. Corpus architecturae religiosae europeae to dokazuje.

Zato optimistično mislim da ćemo kad-tad i druge korpuse moći ostvariti.

Ivanka Reberski, ravnateljica Instituta za povijest umjetnosti u razdoblju od ig88. do 2002. godine i zaslužna znanstvenica, analizirala je u prvom redu problematiku rada na umjetničkoj topografiji Hrvatske, koju Institut za povijest umjetnosti u svom programu vodi već više od tri desetljeća.

\section{Ivanka Reberski - Umjetnička topografija Hrvatske: uspostavljanje projekta, razrada i dosadašnji rezultati}

Umjetnička topografija Hrvatske (UTH) kao temeljni zadatak povije- 
snoumjetničke struke na izradi umjetničkog inventara, pokrenuta je u Institutu za povijest umjetnosti ig82. godine pod vodstvom Milana Preloga, koji je bio njezin idejni začetnik. Kako je prema zatečenom stanju spomenička baština na priobalnom dalmatinskom području već tada bila temeljitije istražena u odnosu na ostale regije kontinentalne Hrvatske, projekt UTH započeo je s najmanje istraženim umjetničko-topografskim arealom, a to je sjeverna Hrvatska.

Prvi metodološki uzorak umjetničko-topografskog pregleda razrađen je osamdesetih godina na primjeru grada Koprivnice (Kopriunica-grad i spomenici, Ig86., knj. I). Daljnja razrada metodologije pod vodstvom Žarka Domljana utvrđena je na većem geografskom uzorku koji je obuhvatio Križevce, grad kontinentalne Hrvatske srednje veličine, i njemu prirodno gravitirajuća dvadeset i dva okolna naselja (Križevci-grad $i$ okolica, I993., knj. 2). Taj se model, uz neznatne modifikacije, uspješno potvrdio u obradi Ludbreške Podravine, koja obuhvaća četiri općine sa središtem u Ludbregu (projekt je finaliziran i objavljen pod naslovom Ludbreg-Ludbreška Podravina, I997., knj. 3).

Široko zasnovan interdisciplinarni pristup glavno je metodološko obilježje spomenutih dionica umjetničke topografije. Modeli tih topografskih dionica obuhvatili su cjelokupni kulturno-povijesni kontekst i razvoj materijalne kulturne baštine, a ne samo povijesnoumjetničko stvaralaštvo određenog područja.

$\mathrm{Na}$ te modele nadovezao se prostor Krapinsko-zagorske županije s njezine trideset i dvije općine (upravno-administrativne jedinice). Ona se ujedno sadržajno i metodološki razlikuje već po tome što joj je težište na građi koja u pravom smislu sačinjava „umjetničku topografiju” područja, a to je stvarni registar zatečenog sakralnog i profanog umjetničkog inventara raspoređenog prema njihovu topografskom razmještaju u prostoru. Projekt je djelomično dovršen objavljivanjem opsežnog sveska pod naslovom Krapinsko-zagorska županija. Sakralna arhitektura s inventarom. Feudalna arhitektura. Spomen-obilježja, Zagreb, 2008. (sunakladnik Školska knjiga). U izradi je peta dionica UTH, koja obuhvaća sjevernohrvatski prostor naselja Ivanec i okolice, pod vodstvom Katarine Horvat-Levaj.

Temeljni sadržaj projekta UTH obuhvaća spomenike sakralne arhitekture i njihov umjetnički inventar (crkvene i liturgijske opreme); potom feudalnu arhitekturu vlastelinskih gradova, dvoraca i kurija te spomen-obilježja (pilova, poklonaca i javnih spomenika). Donekle stoga što je crkveni i feudalni spomenički inventar na tom oduvijek perifernu području sjeverozapadne Hrvatske najugroženiji, ta je vrijedna baština pokretnog i nepokretnog umjetničkog inventara dobila prioritet pri obradi i objavljivanju. Povijesna naselja s gradogradnjom, arheološkim lokalitetima i nalazima najranijih pretpovijesnih tragova života na ovom prostoru trebala su biti obrađena i objavljena kao zasebna cjelina. No taj dio posla do danas nije obavljen.

Budući da ta vrsta istraživanja nadilazi napore pojedinca, u realizaciji tog opsežnog zadatka sudjelovala je ekipa povjesničara umjetnosti iz Instituta za povijest umjetnosti sa suradnicima iz drugih ustanova (Muzeja za umjetnost i obrt, Filozofskog fakulteta u Zagrebu i inih), specijaliziranih za pojedine vrste spomenika. Uglavnom su to povjesničari umjetnosti s iskustvom na tom poslu, uz nezaobilaznu suradnju pratećih stručnih službi arhitekata i fotografa. Pritom je nezaobilazna suradnja povjesničara, arheologa i etnologa. Iz svega je jasno da realizacija projekta umjetničke topografije ovisi o stručnoj i nadasve relevantnoj 
specijalističkoj ekipiranosti istraživača i ostalih sudionika te o raspoloživim sredstvima za pokrivanje troškova.

Usporedno s radom na dokumentiranju i snimanju pojedinih spomenika i predmeta na terenu odvijaju se arhivska istraživanja i pregled relevantne literature, crkvenih vizitacija, spomenica i druge arhivske i dokumentarne građe. Znanstvena i kataloška interpretacija pojedinih jedinica, spomenika i umjetnina završni je dio istraživačkog rada. Nakon što su dovršeni i prikupljeni tekstovi pojedinih dionica započinje redaktorski posao na usklađivanju i ujednačavanju različitih autorskih pristupa i njihova svođenja na odgovarajuću informacijsku razinu.

Količina građe-koja je primjerice u Krapinsko-zagorskoj županiji obuhvatila 32 općine, I48 lokaliteta i oko 290 pojedinačnih spomenika, od kojih je više od polovine sakralnih spomenika s opsežnim inventarom-nametnula je nekoliko ključnih pitanja vezanih uz uređivačku koncepciju. Ponajprije, utvrđivanje kriterija za izbor umjetničkog inventara i njegovo uvrštavanje u ovu knjigu. Sam termin „umjetnički inventar" uvelike razrješuje pitanje kriterija za izbor. On se, dakle, mora temeljiti na umjetničkim vrijednostima, no ponegdje se izbor ipak proteže i na umjetnički manje vrijedne spomeničke objekte ili predmete koji u lokalnim okvirima imaju značaj povijesne memorije. Drugi problem metodološkog je značaja, a odnosi se prije svega na sadržajnu strukturu, odnosno na opseg i ustroj verbalnih i vizualnih informacija.

Prihvaćeni model umjetničke topografije Hrvatske sadržava inventar sakralne i feudalne arhitekture, umjetnički inventar slikarstva, kiparstva i ostale crkvene i liturgijske opreme, a posebni dio odnosi se na povijesni razvoj urbanih i ruralnih naselja. Glavni sadržaj, a to je opis spomenika, s osnovnim informacijama i dokumentarnim ilustracijama, sadržan je u kataloškom dijelu, kojemu prethode kraća uvodna poglavlja sažetih prikaza bitnih povijesnoumjetničkih značajki i tipologije arhitekture, slikarstva, kiparstva i crkvenih predmeta umjetnog obrta. Kataloški dio razvrstan je abecednim redom prema općinama, unutar općina nižu se naselja, također abecedno, sa središnjim mjestom općine na početku niza. Unutar naselja navedeni su opisi pojedinih spomenika i njihova inventara, i to ovim slijedom: sakralni spomenici arhitekture (župna crkva, kapela, poklonci, raspela); iza opisa crkava dolaze opisi crkvene opreme (zidno slikarstvo, oltari i kipovi, štafelajno slikarstvo, namještaj i orgulje te liturgijsko posuđe i ruho), a nakon sakralnih spomenika nižu se opisi vlastelinskih burgova, dvoraca, kurija i javne skulpture. Radi preglednijeg uvida u raspored spomenika u prostoru, kataloški dio popraćen je kartama s ucrtanim granicama općina i naznačenim spomenicima (karta sakralnih spomenika i karta feudalne arhitekture), a ispred svake općine dolazi karta s naznačenim spomenicima. Opisi spomeničkog inventara popraćeni su ilustrativnim prilozima, fotografijama i nacrtima pojedinih spomenika i umjetničkih predmeta.

Iako su spomenuta četiri projekta umjetničke topografije (Koprivnica, Križevci, Ludbreška Podravina i Krapinsko-zagorska županija) realizirana i objavljena, u usporedbi s cjelovitim geografskim prostorom Hrvatske to je tek malen, gotovo bismo rekli neznatan, dio cjeline koju još valja obraditi. Čitava Slavonija, središnja kontinentalna Hrvatska, Istra, Kvarner, Primorje i Dalmacija te jadranski otočki arhipelag uopće nisu ni dodirnuti. Umjetničko nasljeđe na tim prostorima nije ni u kom slučaju ostalo neobrađeno, u posljednje vrijeme postoje i veći projekti, posebice s crkvene strane (Zadarska nadbiskupija, ${ }^{1}$

I JAKŠIC, RADOSLAV TOMIC, Umjetnička baština Zadarske nadbiskupije. Zlatarstvo, Zadar, Zadarska nadbiskupija, 2004;: EMIL HILJE, RADOSLAV TOMIĆ, Umjetnička baština Zadarske nadbiskupije. Slikarstvo, Zadar, Zadarska nadbiskupija, 20o6.; EMIL HILJE, NIKOLA JAKŠIĆ, Umjetnička baština Zadarske nadbiskupije. Kiparstvo I. Od IV. do XVI. stoljeća, Zadar, Zadarska nadbiskupija, 2008.; RADOSLAV томIĆ, Umjetnička baština Zadarske nadbiskupije. Kiparstvo II. Od XVI. do XX. stoljeća, Zadar, Zadarska nadbiskupija, 2008. 
Porečko-pulska biskupija² ${ }^{2}$. Ipak, sva građa nije sistematizirana ni obrađena prema kriterijima i modelu umjetničke topografije. To znači da taj tip projekta još ostaje kapitalan i prioritetan zadatak povijesnoumjetničke struke u Hrvatskoj.

Razlog nedovršenosti projekata te vrste leži ponajprije u nedostatnoj ekipiranosti specijalističkih kadrova, a slijede neadekvatna opremljenost i nedostatak sredstava. Za ostvarenje projekta o kojem je riječ potrebna je usklađena povezanost unutar struke, tj. stručnih područja relevantnih za realizaciju projekta $s$ uključivanjem odgovarajućih znanstvenih institucija, muzeja i galerija te napose zavoda za zaštitu spomenika kulture, koji su najpozvaniji i najupućeniji kad je riječ o umjetničkom nasljeđu na pripadnom terenu. Kad je riječ o troškovima, valja istaknuti: umjetnička topografija ne može se ostvariti kabinetskim radom. Za nju je nužan terenski rad, a on iziskuje razmjerno velika financijska sredstva, kojima se, između ostalog, pokriva i mobilnost organiziranog tima na terenu.

U radu panela sudjelovao je i Tonko Maroević, znanstvenik emeritus u Institutu za povijest umjetnosti, koji se osvrnuo na pisanje monografija o umjetnicima i umjetničkim fenomenima te na problematiku istraživanja i prezentacije umjetnika i njihovih opusa u Hrvatskoj.

* Okrugli stol o ključnim infrastrukturnim projektima hrvatske povijesti umjetnosti rezimirao je najvažnije spoznaje o njihovu historijatu i zaprekama u njihovu ostvarivanju. Najbolji su rezultati postignuti u području monografske obrade opusa umjetnika i umjetničkih fenomena. Oni proizlaze iz više-manje samostalna rada pojedinih znanstvenika. Dugotrajniji projekti koji pretpostavljaju sustavno i koordinirano djelovanje timova istraživača i stručnih suradnika u povezanim institucijama iz različitih se (objektivnih i subjektivnih) razloga mnogo teže i sporije ostvaruju.

Bez obzira na to čini se da je ipak utemeljen umjereni optimizam kad je riječ o izradi sinteznih pregleda hrvatske povijesti umjetnosti za razdoblja koja još nisu pokrivena. Isto vrijedi i za ostvarenje cjelovite umjetničke topografije Hrvatske prema nekom suvremenijem i podesnijem modelu. Izrada korpusa kao dugotrajan, samozatajan i mukotrpan posao u struci dat će također rezultate, no oni će ovisiti o ustrajnosti i organiziranosti njihovih nositelja. U tome se naposljetku opet iskazuje važnost institucija, odnosno njihova spremnost i sposobnost da organiziraju i koordiniraju rad na još nepotpunoj infrastrukturi hrvatske povijesti umjetnosti.

\section{() (1)}

(NE) OSTVARENO

Strateški istraživački i nakladnički projekti hrvatske povijesti umjetnosti: sinteza-umjetnička topografija-korpusi-monografije/ Milan Pelc, Žarko Domljan, Miljenko Jurković, Tonko Maroević, Ivanka Reberski / CC BY / 4.o

DOI: https://doi.org/Io.31664/z4khpu.38
IVAN MATEJČIĆ, SUNČICA MUSTAČ et al., Kiparstvo od 4. do I3. stoljeća. Umjetnička baština istarske crkve I / Scultura dal IV al XIII secolo. Il patrimonio artistico della chiesa istriana I, Poreč, Porečka i Pulska biskupija, Istarska županija, Istarska kulturna agencija, 2OI4.; PREDRAG MARKOVIĆ, IVAN MATEJČIĆ, DAMIR TULIĆ, Kiparstvo od I4. do I8. stoljeća. Umjetnička baština istarske crkve 2 / Scultura dal XIV al XVIII secolo. Il patrimonio artistico della chiesa istriana 2, Pula, Istarska kulturna agencija, Porečka i Pulska biskupija, Istarska županija, Arheološki muzej Istre, Josip Turčinović d. o. o., 20I7. 